\title{
What controls local-scale aboveground biomass variation in central Africa? Testing structural, composition and architectural attributes
}

\author{
Grace Jopaul Loubota Panzou ${ }^{\mathrm{a}, \mathrm{b}, *}$, Adeline Fayolle ${ }^{\mathrm{a}}$, Ted R. Feldpausch ${ }^{\mathrm{c}}$, Gauthier Ligot ${ }^{\mathrm{a}}$, \\ Jean-Louis Doucet $^{\mathrm{a}}$, Eric Forni ${ }^{\mathrm{d}}$, Isaac Zombo ${ }^{\mathrm{e}}$, Mathurin Mazengue ${ }^{\mathrm{f}}$, Jean-Joël Loumeto ${ }^{\mathrm{b}}$, \\ Sylvie Gourlet-Fleury ${ }^{\mathrm{d}}$ \\ a TERRA Teaching and Research Center, Forest is life, Gembloux Agro-Bio Tech (Liège Université), Passage des Déportés, 2-5030 Gembloux, Belgium \\ ${ }^{\mathrm{b}}$ Laboratoire de Botanique et Ecologie, Faculté des Sciences et Techniques (Université Marien Ngouabi), BP 69 Brazzaville, Republic of Congo \\ ${ }^{\mathrm{c}}$ Geography, College of Life and Environmental Sciences, University of Exeter, Exeter EX4 4RJ, UK \\ ${ }^{\mathrm{d}}$ CIRAD, Forêts et Sociétés, Université de Montpellier, 34398 Montpellier, France \\ e CIB-Olam, BP 41 Ouesso, Republic of Congo \\ ${ }^{\mathrm{f}}$ Mokabi S.A., BP 97 Impfondo, Republic of Congo
}

A R T I C L E IN F O

\section{Keywords:}

Tree allometry

AGB estimation

Basal area

Wood density

Total height

Crown size

Central Africa

\begin{abstract}
A B S T R A C T
Tropical forests play a key role in regulating the terrestrial carbon cycle and climate change by storing a large amount of carbon. Yet, there is considerable uncertainty about the amount and spatial variation of aboveground biomass (AGB), especially in the relatively less studied African tropical forests. In this study, we explore the local-scale variation and determinants of plot-level AGB, between and within two types of forests, the Celtis and Manilkara forests, growing under the same climate but on different geological substrates in the northern Republic of Congo. In each forest site, all trees $\geq 10 \mathrm{~cm}$ diameter were censured in $36 \times 1$-ha plots and we measured tree height and crown size using a subsample of $18 \times 1$-ha of these plots. We developed heightdiameter and crown-diameter allometric relationships and tested whether they differed between the two sites. For each 1-ha plot, we further estimated the AGB and calculated structural attributes (stem density and basal area), composition attributes (wood density) and architectural attributes (tree height and crown size), the latter being derived from site-specific allometric relationships. We found strong between-site differences in heightdiameter and crown-diameter allometries. For a given diameter, trees were taller in the Celtis forest while they had larger crown in the Manilkara forest. Similar trends were found for the sixteen species present in both forest sites, suggesting an environmental control of tree allometry. Although there were some between-site differences in forest structure, composition and architecture, we did not detect any significant difference in mean AGB between the Celtis and the Manilkara forests. The AGB variation was related to the heterogeneous distribution of large trees, and influenced by basal area, height and crown dimensions, and to a lesser extent wood density. These forest attributes have strong practical implications on emerging remote-sensing technologies for carbon monitoring in tropical forests.
\end{abstract}

\section{Introduction}

Tropical forests play a key role in regulating the terrestrial carbon cycle and climate change by storing carbon in the wood (Pan et al., 2011). The above ground biomass (AGB) of trees indeed constitutes the major carbon pool in tropical forests (Eggleston et al., 2006). Current efforts to map and monitor carbon stocks in tropical forests worldwide (Saatchi et al., 2011; Avitabile et al., 2016), that are needed for the implementation of climate change mitigation strategies, such as REDD + , rely on robust AGB estimates in specific sites that are used for the calibration of remotely-sensed products. AGB estimates at large-scale are still fraught with uncertainty (Mitchard et al., 2014), because environmental variation is rarely accounted for when local AGB estimates are extrapolated at these scales.

A huge variation in plot-level AGB has been demonstrated, at large scale in old-growth tropical forests between continents (Slik et al., 2013) and across tropical Africa (Lewis et al., 2013), and at local scale in central Africa (Gourlet-Fleury et al., 2011; Doetterl et al., 2015; Fayolle et al., 2016; Imani et al., 2017). Plot-level AGB variation is determined by variation in forest structure, composition, and

\footnotetext{
* Corresponding author at: Passage des Déportés, 2-5030 Gembloux, Belgique.

E-mail address: loubotagrace@gmail.com (G.J. Loubota Panzou).
} 
architecture (Asner et al., 2012). Firstly, the two main structural attributes driving forest AGB are forest basal area and the density of large trees. As tree AGB increases with tree diameter, there is logically a strong relationship between plot-level AGB and basal area. Indeed, among all structural attributes, basal area is recognized as the most important determinant of plot-level AGB, and the relationship between AGB and basal area has been evidenced throughout tropical forests (Lewis et al., 2013; Imani et al., 2017). More recently, the importance of large trees has been highlighted (Bastin et al., 2015; Lutz et al., 2018), and specifically the density of trees greater than $70 \mathrm{~cm}$ in diameter has been shown to explain AGB variation between and within continents (Slik et al., 2013). These large trees could be more easily monitored with remote sensing techniques and then could be an interesting predictor of AGB at large scale (Meyer et al., 2018). Secondly, the variation in species composition, and specifically in mean plot-level wood density, has been found to determine spatial patterns in AGB across forests in Amazonia (Baker et al., 2004) and Africa (Lewis et al., 2013). Forests dominated by dense-wooded species often have high AGB. In central Africa, the high wood density of forests growing on sandy soils has particularly been shown to store large amounts of AGB despite showing relatively low basal area (Gourlet-Fleury et al., 2011). Thirdly, architectural attributes, through canopy height and area computed from tree height and crown measurements, are also important determinants of plot-level AGB. Among architectural attributes the plot-aggregate allometry based on Lorey's height, which is the basal area-weighted height of all trees in a plot, is the most popular ones, because of its widespread use in AGB maps through LiDAR sensors (Saatchi et al., 2011). Plot-level canopy area could also explain AGB variations, as recently evidenced in the Neotropics (Meyer et al., 2018).

Structural, composition and architectural attributes at the plot level are typically computed from forest inventory data, i.e. from all or a subsample of trees in a plot. In most tropical forest inventories, only tree diameter and species names are recorded which allow quantifying the forest structural (basal area, density) and composition (mean wood density from species average) attributes. In contrast, architectural measurements (tree height and crown size) are rarely available for all trees and frequently modelled from a subsampling of trees within inventory plots. As a consequence, height-diameter and crown size allometric models are applied to estimate the height and crown size for the remaining trees (Feldpausch et al., 2012), in order to compute architectural attributes at the plot level. Several studies showed that using height-diameter allometric relationships established at a global scale (Lewis et al., 2009) and at a regional scale (Feldpausch et al., 2012; Lewis et al., 2013) leads to significant biases in plot-level AGB estimates. There is a consensus on the need for local site-specific allometric models to provide reliable AGB estimates at the tree (Chave et al., 2014) and the plot level (Sullivan et al., 2018) across the tropics, and in central Africa (Kearsley et al., 2013; Fayolle et al., 2016). Furthermore, it has been recently demonstrated that crown radius improves AGB estimates for tropical trees, in addition to more classical AGB determinants, namely tree diameter, wood density and total tree height (Goodman et al., 2014; Ploton et al., 2016). The variation in crowndiameter allometry (Antin et al., 2013; Blanchard et al., 2016) and the consequences on plot-level AGB variation has yet been little explored in tropical forests.

The relative contribution of forest structure, composition, and architecture to plot-level AGB variation has been poorly explored, specifically in central Africa, where little is known about the amount and spatial variation of AGB (Loubota Panzou et al., 2016) and which remain relatively understudied (Verbeeck et al., 2011). There is a need for efficient methods to monitor forest AGB that could adapt to local site conditions, given the huge variability of AGB across tropical forests and the multiplicity of factors in play. We thus explored, using a new network of $72 \times 1$ ha permanent plots, the local-scale variation and determinants of plot-level AGB, between and within the two mixed forest types, Celtis and Manilkara forests, growing under the same climate but on different geological substrates (Fayolle et al., 2012, 2014). These forest types show contrasted successional dynamics and traits (RéjouMéchain et al., 2014), and vastly different composition and structure in the later successional stage, but similar AGB (Gourlet-Fleury et al., 2011). We first tested whether height-diameter and crown allometries differed between the two forest sites. Then, we investigated how between and within-site AGB variation were related to structural, composition and architectural attributes, the latter being derived from our site-specific allometries.

\section{Material and methods}

\subsection{Study sites}

Two study sites, representative of the Celtis and Manilkara forests which are mixed forest types, were inventoried in the northern Republic of Congo. The Celtis forest site is located in the LoundoungouToukoulaka forest concession $\left(2^{\circ} 20^{\prime} \mathrm{N}, 17^{\circ} 32^{\prime} \mathrm{E}\right)$ managed by the CIBOlam company. The canopy of this forest type is dominated by light demanding tree species such as Celtis spp., Erythrophleum suaveolens and Petersianthus macrocarpus (Fayolle et al., 2014). The geological substrate consists of alluvium (Fayolle et al., 2012). The Manilkara forest site is located in the Mokabi-Dzanga forest concession $\left(3^{\circ} 19^{\prime} \mathrm{N}, 16^{\circ} 76^{\prime} \mathrm{E}\right)$ managed by the Rougier company. The canopy is enriched by many slow-growing shade tolerant species that have a high mean wood density, such as Manilkara, Staudtia species (Fayolle et al., 2014). The geological substrate consists of sandstone that led to poor and highly drained soils (Fayolle et al., 2012). In both forest sites, the mean annual precipitation is around $1600 \mathrm{~mm}$ with a distinct dry season (December until March, with $<100 \mathrm{~mm} \cdot$ month $^{-1}$ ). The mean annual temperature is $25^{\circ} \mathrm{C}$. The topography is slightly undulating, with elevation varying between 400 and $550 \mathrm{~m}$.

\subsection{Tree measurements}

In each forest site, field work was carried out in an unlogged area within a 800-ha experimental design (DynAfFor project, www.dynaffor. org). In this experimental design, 36 permanent 1-ha plots were installed and distributed within four blocks. Each block contained nine juxtaposed plots of $100 \times 100 \mathrm{~m}$ ( $1 \mathrm{ha}$ ) and all trees with diameter $\geq 10 \mathrm{~cm}$ were inventoried and identified to species level by a botanist. A subsample of two blocks was used to measure tree height and crown dimensions. In each block, all trees $\geq 10 \mathrm{~cm}$ diameter were measured in the central 1-ha plot and one large tree was additionally sampled in the remaining 8 plots following a grid of $20 \mathrm{~m} \times 20 \mathrm{~m}$. A total of 2202 trees ( $n=1040$ trees for the Celtis forest and $n=1162$ trees for the Manilkara forest) were measured in the plots over a large range of diameters from 10 to $162 \mathrm{~cm}$. Moreover, we selected the most abundant species shared by the two forest sites ( $\mathrm{n}=16$ species, Appendix A) and sampled their whole diameter range using additional trees measured outside the plots but within the 800-ha experimental design to complete the diameter range.

Tree diameter ( $\mathrm{D}$ in $\mathrm{cm}$ ) was measured with a tape at $1.3 \mathrm{~m}$ for regular stems or above the top of the buttresses for irregular stems. Total height $(H$ in $\mathrm{m})$ and height to the first branch $(H b$ in $\mathrm{m})$ were measured with a VERTEX IV Rangefinder. Crown depth ( $C d$ in $\mathrm{m}$ ) was defined as the length of the crown, calculated from the difference between $H$ and $H b$. Crown radius ( $\mathrm{Cr}$ in $\mathrm{m}$ ) was defined as the average of four perpendicular projected crown radii measured according to the four cardinal directions.

\subsection{Site-specific allometric models}

We developed site-specific height-diameter allometric equations using the Michaelis-Menten model. Asymptotic models have been demonstrated to better describe height-diameter allometry for AGB 
estimation in tropical forests (Sullivan et al., 2018), and the MichaelisMenten model was found to provide good fit to height-diameter data in central Africa (Fayolle et al., 2016). The model form is:

$H_{i s}=a_{s} \times D_{i s} /\left(b_{s}+D_{i s}\right)$

where $\mathrm{a}_{\mathrm{s}}$ and $\mathrm{b}_{\mathrm{s}}$ are site-specific parameters, $H_{\mathrm{is}}$ (in $\mathrm{m}$ ) and $D_{\text {is }}$ (in $\mathrm{cm}$ ) represent, respectively, the total height and the diameter of tree $i$ within each site $s$.

The height to the first branch-diameter, the crown depth-diameter and the crown radius-diameter allometries were fitted using power models that were linearized using log-log transformation:

$y_{i s}=a_{s} \times D_{i s} b_{s} \leftrightarrow \log \left(y_{i s}\right)=\log \left(a_{s}\right)+b_{s} \log \left(D_{i s}\right)$

where $a_{s}$ and $b_{s}$ are fitted parameters, $y$ is alternatively the height to the first branch $\left(H b_{\text {is }}\right.$ in $\left.\mathrm{m}\right)$, the crown depth $\left(C d_{\text {is }}\right.$ in $\left.\mathrm{m}\right)$ or the crown radius $\left(C r_{\text {is }}\right.$ in $\mathrm{m}$ ) of tree $i$ belonging to site $s$.

To test for a significant difference in tree allometry between the two sites, we fitted on the whole data set four models: (i) a general model with fixed parameters ( $a$ and $b$ ) for all sites, (ii) varying $a_{s}$ and $b_{s}$, (iii) varying $a_{s}$ and fixed $b$, and (iv) fixed a and varying $b_{s}$. For each allometric relationship, the model selection was based on (i) the likelihood ratio test that is a statistical test used for comparing the goodness of fit of two statistical models (the null model with fixed coefficients, and the alternative model with varying coefficients); and (ii) the Akaike's Information Criterion (AIC) for model selection, with the lowest AIC indicating the best model (Akaike, 1974).

\subsection{AGB estimation}

To estimate the AGB (in $\mathrm{Mg}$ ) of each tree in the $36 \times 1$-ha plots sampled in the Celtis and Manilkara forests, we used the most recent pantropical allometric equation of Chave et al. (2014):

$A G B=0.0673 \times\left(\rho D^{2} H\right)^{0.976}$

Tree diameter $(D$ in $\mathrm{cm})$ was directly available from the forest inventory. Each stem in the plot was assigned a wood density value ( $\rho$ in $\mathrm{g} \cdot \mathrm{cm}^{-3}$ ), corresponding to the species average from the global wood density database (Chave et al., 2009; Zanne et al., 2009) when possible, and if not, to a genus-, family- or plot level average. Tree diameters from the forest inventory data were converted into tree height estimates ( $H$ in $\mathrm{m}$ ) using the site-specific height-diameter allometric model (1). Lastly, tree AGB was summed at the 1-ha plot level.

\subsection{Forest structural, composition and architectural attributes}

For each 1-ha plot, we calculated five structural attributes: stem density $(S D)$, basal area $\left(B A\right.$ in $\left.\mathrm{m}^{2}\right)$, stem density and basal area of large trees ( $\geq 70 \mathrm{~cm}$ diameter, named $S D_{70}$ and $B A_{70}$ ) and maximum tree diameter $\left(D_{\max }\right.$ in $\left.\mathrm{cm}\right)$. $S D$ was the number of trees greater than or equal to $10 \mathrm{~cm}$ diameter per hectare. $B A$ was calculated as the sum of the cross-section area at $1.30 \mathrm{~m}$, or above buttresses, of all trees $\geq 10 \mathrm{~cm}$ diameter. $D_{\max }$ was calculated as the 98-percentile stem diameter of the sampled trees for each plot.

The forest composition has been assessed through the mean wood density $\left(W D_{\mathrm{m}}\right.$ in $\left.\mathrm{g} \cdot \mathrm{cm}^{-3}\right)$ and $B A$-weighted wood density $\left(W D_{\mathrm{BA}}\right.$ in $\mathrm{g} \cdot \mathrm{cm}^{-3}$ ) at 1 -ha plot level.

The forest architecture is the expression of the vertical (tree height and crown depth) and horizontal (crown radius) structure. We converted the diameter of all trees in the $36 \times 1$-ha permanent plots into tree height and crown dimensions (radius and depth) using the sitespecific height-diameter and crown allometric equations. Similarly forest composition, two architectural attributes (mean across all trees and $B A$-weighted mean) were calculated at the plot-level for the height, for the crown depth, and for the crown radius.

\subsection{Data analysis}

Two-way ANOVA including block and site as random factors was used to test the plot-level AGB variation between the two forest sites. We then provided for each forest site, pooling the 36 permanent plots, the AGB distribution by $10-\mathrm{cm}$ wide diameter class. The AGB distribution was completed with the cumulative curve of AGB, showing the increase of AGB from the smallest to the largest diameter class. We used two-way ANOVA to test the between-site differences in AGB for three diameter size classes: the lower stratum with small trees $(10 \leq \mathrm{D}<30 \mathrm{~cm})$, the middle stratum with large trees, most of which reach the canopy $(30 \mathrm{~cm} \leq \mathrm{D}<70 \mathrm{~cm})$, and the upper stratum corresponding to the largest trees, which were either in the canopy or emergent, with diameter $\geq 70 \mathrm{~cm}$ (Slik et al., 2013).

We tested the plot-level forest attributes variation between the two forest sites using two-way ANOVA including block and site as random factors. To determine whether 1-ha plot AGB was related to forest structural, composition and architectural attributes, we computed Pearson correlations within and between the two forest sites as well as more integrative mixed linear models in which forest attributes were included as a covariate and site and block were included as random variables in order to account for the nestedness of the data. In addition, we studied the relationships between AGB and forest attributes using ordinary least-square regressions to determine the importance of forest attributes on AGB variation within each forest site at plot-level.

All the above statistical analyses were performed within the open source $R$ environment ( $R$ version 3.4.1, $R$ Core Team, 2017) using the nlme package (Pinheiro et al., 2017) and BIOMASS package (RéjouMéchain et al., 2017). The conditions of normality and homoscedasticity of residuals were checked graphically and with ShapiroWilk and Breusch-Pagan tests, respectively. For the ANOVA test, the null hypothesis was "no difference between means for each variable". When the null hypothesis was rejected, we conducted post-hoc pairwise multiple comparisons between means. All significant differences reported to $P$-value $<0.05$.

\section{Results}

\subsection{Tree allometry}

We identified a significant variation in tree allometry between the Celtis and the Manilkara forests (Fig. 1). Based on AIC, we found a site effect on one model parameter for height-diameter allometry, and on the two model parameters for the height to the first branch-diameter, the crown depth-diameter and the crown radius-diameter allometries (Table 1). For a given diameter, trees were taller and had a deeper crown in the Celtis forest whereas the height to the first branch was higher, and the crown larger in the Manilkara forest. Similar trends were found in height-diameter and crown allometries for the sixteen species shared by both forest sites (Fig. 1, Table 1). We did not evidence strong variation in the first branch height-diameter allometry for shared species and only little variation for all species. This result indicates that total height-diameter allometry is mostly governed by crown depth.

\subsection{AGB distribution}

We did not detect any significant difference in mean AGB between the Celtis and the Manilkara forests (Table 2), and for the two forest sites, a large fraction of AGB is stored in the largest stems, with $50 \%$ of the total AGB stored in the trees larger than $80 \mathrm{~cm}$ (Fig. 2a). However, AGB distribution among $10 \mathrm{~cm}$ wide diameter classes reflected sitespecific patterns, with higher AGB stored in the largest stems in the Celtis forest (Fig. 2a). Indeed, the AGB of the trees with diameter $\geq 70 \mathrm{~cm}$ significantly differed between the two forest sites with a higher AGB in the Celtis forest (Fig. 2b). In contrast, the AGB stored in the two lower strata $(10-30 \mathrm{~cm}$ and $30-70 \mathrm{~cm}$ in diameter) was not significantly 

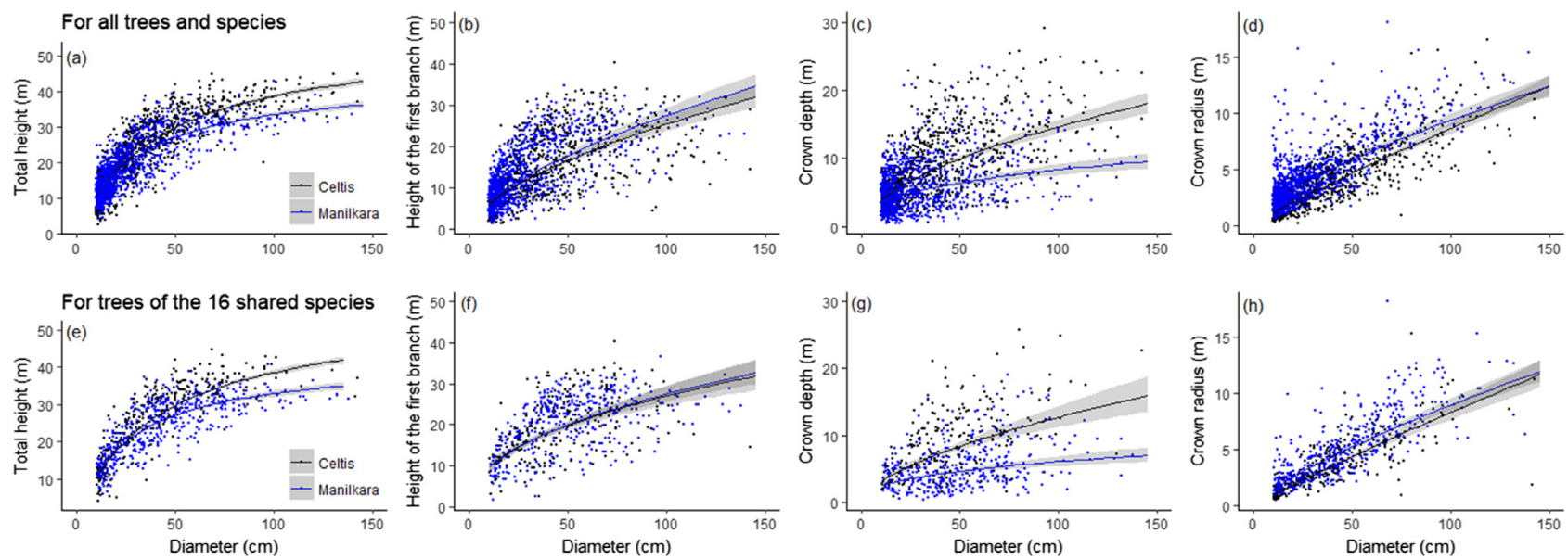

Fig. 1. Site-specific allometric relationships between tree diameter and total height fitted with the Michaelis Menten model, and between tree diameter and height to the first branch, crown depth, and crown radius, fitted with a power model, for all trees and species (a-d) and for the trees of the 16 species shared by the two forest sites (e-h). The colour of symbols and curves corresponds to the forest site, i.e. the Celtis (black) and the Manilkara (blue) forests. The $95 \%$ confidence intervals of model predictions are shown in grey. (For interpretation of the references to color in this figure legend, the reader is referred to the web version of this article.)

different between the two forest sites, despite the larger number of small trees in the Manilkara forest, their respective AGB was only slightly higher (Fig. 2b).

In both sites, we detected strong local-scale variation in plot-level AGB estimates that ranged from 242 to $549 \mathrm{Mg} \mathrm{ha}^{-1}$ with a coefficient of variation of $18 \%$ in the Celtis forest, and from 305 to $464 \mathrm{Mg} \mathrm{ha}^{-1}$ with a coefficient of variation of $10 \%$ in the Manilkara forest. In the Celtis forest, the AGB stored in the largest trees was even more variable across plots (Fig. 2b).

\subsection{Forest attributes and relationships with $A G B$}

At plot-level, we found that the Celtis and the Manilkara forests vastly differed in forest structure, composition and architecture (Table 2). The Celtis forest had a significantly higher density of large trees $\left(S D_{70}\right)$, greater maximum tree diameter $\left(D_{\max }\right)$, higher total tree height $\left(H_{\mathrm{m}}\right.$ and $\left.H_{\mathrm{BA}}\right)$, deeper crown $\left(C d_{\mathrm{m}}\right.$ and $\left.C d_{\mathrm{BA}}\right)$ and larger crown $\left(\mathrm{Cr}_{\mathrm{m}}\right.$ and $\left.\mathrm{Cr}_{\mathrm{BA}}\right)$; while the Manilkara forest had a significantly higher stem density $(S D)$ and wood density $\left(W D_{\mathrm{m}}\right.$ and $\left.W D_{\mathrm{BA}}\right)$.

Plot-level AGB, including between- and within-site variation, was found to be correlated to most forest attributes (Table 3). With the exception of $S D$ and $H_{\mathrm{m}}$, we found strong correlations between plotlevel AGB and most structural and architectural attributes. These relationships were retrieved, separately for the Celtis and for the Manilkara forest, and using the combined dataset. In contrast, composition
Table 2

Between-site differences in forest attributes: forest structure (stem density, $S D$, basal area, $B A$ in $\mathrm{m}^{2}$, stem density of large trees, $S D_{70}$, basal area of large trees, $B A_{70}$ in $\mathrm{m}^{2}$ and maximum tree diameter, $D_{\max }$ in $\mathrm{cm}$ ), composition (mean wood density, $W D_{\mathrm{m}}$ and $B A$-weighted wood density, $W D_{\mathrm{BA}}$, in $\mathrm{g} \cdot \mathrm{cm}^{-3}$ ), and architecture (mean total height, $H_{\mathrm{m}}, B A$-weighted total height, $H_{\mathrm{BA}}$, mean crown depth, $C d_{\mathrm{m}}, B A$-weighted crown depth, $C d_{\mathrm{BA}}$, mean crown radius, $C r_{\mathrm{m}}$, and $B A$ weighted crown radius, $C r_{\mathrm{BA}}$, in $\mathrm{m}$ ) and in $\mathrm{AGB}$ (in $\mathrm{Mg}$ ) at the 1-ha plot level. Different letters indicate a significant difference $(P<0.05)$ according to the post-hoc tests.

\begin{tabular}{lllll}
\hline Forest attributes & Celtis & Manilkara & $P$-value \\
\hline \multirow{2}{*}{ Structure } & $S D$ & $350 \pm 35^{\mathrm{a}}$ & $430 \pm 22^{\mathrm{b}}$ & 0.001 \\
& $S D_{70}$ & $15 \pm 4^{\mathrm{a}}$ & $12 \pm 2^{\mathrm{b}}$ & 0.008 \\
& $B A$ & $29.49 \pm 3.44^{\mathrm{a}}$ & $29.48 \pm 2.42^{\mathrm{a}}$ & 0.162 \\
& $B A_{70}$ & $11.28 \pm 4.21^{\mathrm{a}}$ & $8.74 \pm 2.30^{\mathrm{b}}$ & 0.002 \\
& $D_{\max }$ & $86.59 \pm 11.06^{\mathrm{a}}$ & $77.5 \pm 7.53^{\mathrm{b}}$ & 0.001 \\
Composition & $W D_{\mathrm{m}}$ & $0.65 \pm 0.02^{\mathrm{a}}$ & $0.68 \pm 0.01^{\mathrm{b}}$ & 0.001 \\
& $W D_{\mathrm{BA}}$ & $0.65 \pm 0.03^{\mathrm{a}}$ & $0.67 \pm 0.02^{\mathrm{b}}$ & 0.001 \\
\multirow{4}{*}{ Architecture } & $H_{\mathrm{m}}$ & $18.31 \pm 0.53^{\mathrm{a}}$ & $18.03 \pm 0.32^{\mathrm{b}}$ & 0.009 \\
& $H_{\mathrm{BA}}$ & $30.31 \pm 1.58^{\mathrm{a}}$ & $28.47 \pm 0.91^{\mathrm{b}}$ & 0.001 \\
& $C d_{m}$ & $6.29 \pm 0.17^{\mathrm{a}}$ & $6.17 \pm 0.10^{\mathrm{b}}$ & 0.001 \\
& $C d_{B A}$ & $10.88 \pm 0.90^{\mathrm{a}}$ & $9.99 \pm 0.49^{\mathrm{b}}$ & 0.001 \\
& $C r_{\mathrm{m}}$ & $2.46 \pm 0.11^{\mathrm{a}}$ & $2.35 \pm 0.06^{\mathrm{b}}$ & 0.001 \\
& $C r_{\mathrm{BA}}$ & $5.90 \pm 0.85^{\mathrm{a}}$ & $5.14 \pm 0.44^{\mathrm{b}}$ & 0.001 \\
\multirow{2}{*}{ AGB } & $370 \pm 67^{\mathrm{a}}$ & $375 \pm 41^{\mathrm{a}}$ & 0.707 & \\
\hline
\end{tabular}

Table 1

Between-site differences in allometric relationships between tree diameter $(D)$ and: total tree height $(H)$, height to the first branch $(H b)$, crown depth $(C d)$, and crown radius ( $\mathrm{Cr}$ ), for all inventoried trees and species, and for the 16 shared species. For each allometric relationship, we compared a general model with fixed parameters and three alternative models including a site effect on the parameters (site-specific $a_{\mathrm{s}}$ and $b_{\mathrm{s}}$, site-specific $a_{\mathrm{s}}$, and site-specific $b_{\mathrm{s}}$ ) using the AIC values and likelihood ratio tests ( $P$-value). The best models are shown in bold.

\begin{tabular}{|c|c|c|c|c|c|c|c|c|}
\hline & \multicolumn{2}{|c|}{$H-D$ allometry } & \multicolumn{2}{|c|}{$H b-D$ allometry } & \multicolumn{2}{|c|}{$C d-D$ allometry } & \multicolumn{2}{|c|}{$C r-D$ allometry } \\
\hline & AIC & $P$-value & AIC & $P$-value & AIC & $P$-value & AIC & $P$-value \\
\hline \multicolumn{9}{|l|}{ For all trees and species } \\
\hline General model (without site effect) & 12,791 & - & 2118 & - & 3188 & - & 2701 & - \\
\hline Site-specific $a_{s}$ and $b_{s}$ & 11,652 & 0.001 & 2111 & 0.001 & 3007 & 0.001 & 2229 & 0.001 \\
\hline Site-specific $a_{\mathrm{s}}$ and common $b$ & 11,325 & 0.001 & 2109 & 1.000 & 3035 & 0.001 & 2289 & 0.001 \\
\hline Site-specific $b_{s}$ and common $a$ & 12,463 & 0.001 & 2109 & 1.000 & 3014 & 1.000 & 2368 & 1.000 \\
\hline \multicolumn{9}{|l|}{ For trees of the 16 shared species } \\
\hline General model (without site effect) & 4432 & - & 498 & - & 1201 & - & 642 & - \\
\hline Site-specific $a_{s}$ and $b_{s}$ & 4322 & 0.001 & 502 & 0.945 & 1093 & 0.001 & 575 & 0.001 \\
\hline Site-specific $a_{\mathrm{s}}$ and common $b$ & 4311 & 0.001 & 500 & 0.911 & 1096 & 0.017 & 584 & 0.001 \\
\hline Site-specific $b_{s}$ and common $a$ & 4403 & 0.001 & 500 & 0.875 & 1091 & 1.000 & 594 & 1.000 \\
\hline
\end{tabular}



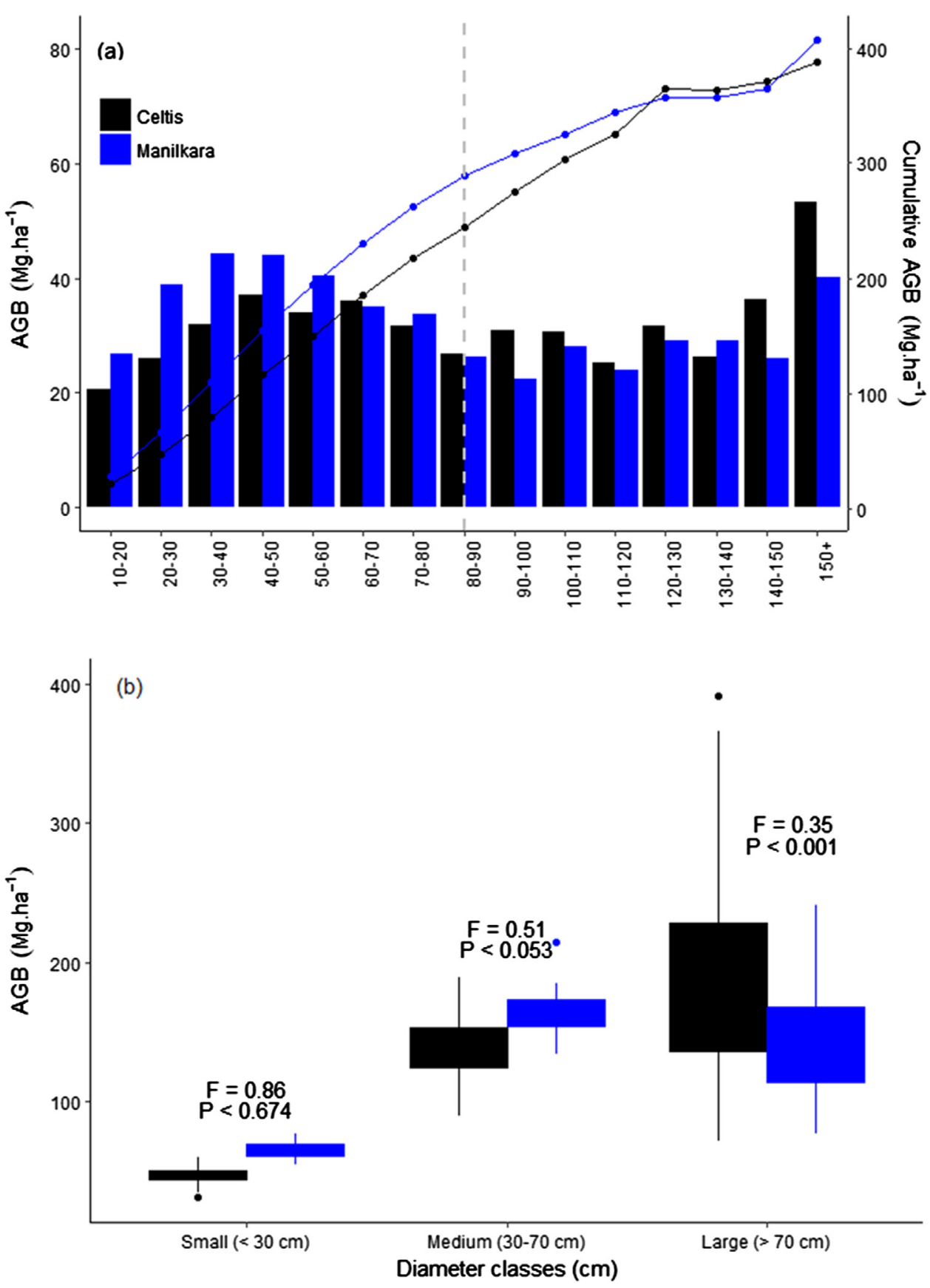

Fig. 2. Distribution of AGB (in $\mathrm{Mg} \mathrm{ha}{ }^{-1}$ ) among 10-cm wide diameter classes (a) and between small (tree diameter $<30 \mathrm{~cm}$ ); medium (tree diameter between 30 and $70 \mathrm{~cm}$ ) and large trees (tree diameter $\geq 70 \mathrm{~cm}, \mathrm{~b}$ ). The cumulative AGB among 10-cm wide diameter classes is also given (a, lines). The vertical dashed line represents the mid-point in cumulative AGB distribution, with $50 \%$ of biomass above and below; this midpoint was found to be the same for the Celtis (black) and the Manilkara (blue) forests. ANOVAs ( $F$-value and associated $P$-value) were used to determine significant between-site differences in AGB contained in the small, medium and large trees. attributes were only correlated with plot-level AGB in the Celtis forest, and using the combined dataset. Similar results were found with mixed linear models in which site and block were included as random factors to account for the nestedness of the data (Table 3).

Because we found significant differences between the two forest sites in linear models relating plot-level AGB to forest attributes (ANCOVAs; results not shown), we fitted site-specific regression lines between plot-level AGB and forest attributes (Fig. 3). Specifically, plotlevel AGB was positively and linearly related with structural attributes $\left(S D_{70}, B A, B A_{70}\right.$ and $\left.D_{\max }\right)$ and architectural attributes $\left(H_{\mathrm{BA}}, C d_{\mathrm{m}}, C d_{\mathrm{BA}}\right.$, $C r_{\mathrm{m}}$ and $C r_{\mathrm{BA}}$ ), and all relationships appeared site-specific. Within both the Celtis and the Manilkara forests, $B A$ was the most important forest attributes for plot-level AGB variation, with almost $90 \%$ of explained variance, followed by $B A_{70}, H_{\mathrm{BA}}, C d_{\mathrm{BA}}$ and $C r_{\mathrm{BA}}$ with almost $70 \%$ of explained variance (Fig. 3). Including site as a covariate in the linear model between plot-level AGB and $B A$ was found to be significant, but the site-specific relationships appeared relatively close, in contrast with the other forest attributes. The picture was slightly different for composition attributes (Fig. 3): plot-level AGB increased slightly with $W D_{\mathrm{m}}$ and $W D_{\mathrm{BA}}$ in the Celtis forest but not in the Manilkara forest (Table 3).

\section{Discussion}

In this study, we found that forest structure (basal area), composition (wood density) and architecture (tree height and crown dimensions) were all significant indicators of 1-ha plot-level AGB variation. The new plot network presented here confirmed the specific structure and composition of the Celtis and Manilkara forests, already identified by Gourlet-Fleury et al. (2011). Here, we also showed contrasted architecture, with the site-specific allometries developed for the precise estimation of AGB at the tree and the plot levels. Interestingly, despite these differences, the two forests store the same amount of AGB, due to compensatory effects. 
Table 3

Relationships between forest attributes and plot-level AGB (in Mg) using Pearson correlation coefficients and mixed linear models. Forest attributes include forest structure (stem density, $S D$, stem density of large trees, $S D_{70}$, basal area, $B A$ in $\mathrm{m}^{2}$, basal area of large trees, $B A_{70}$ in $\mathrm{m}^{2}$ and maximum tree diameter, $D_{\text {max }}$ in cm), composition (mean wood density, $W D_{\mathrm{m}}$ and $B A$-weighted wood density, $W D_{\mathrm{BA}}$, in $\mathrm{g} \cdot \mathrm{cm}^{-3}$ ), and architecture (mean total height, $H_{\mathrm{m}}, B A$-weighted total height, $H_{\mathrm{BA}}$, mean crown depth, $C d_{\mathrm{m}}, B A$-weighted crown depth, $C d_{\mathrm{BA}}$, mean crown radius, $C r_{\mathrm{m}}$, and $B A$-weighted crown radius, $C r_{\mathrm{BA}}$, in $\mathrm{m}$ ). For each relationship, we provided the value and significance $\left({ }^{*} P<0.05 ;{ }^{* * *} P<0.01 ;{ }^{* * * *} P<0.001\right)$ of Pearson correlations coefficients and the results of mixed linear models including site and block as random factors to account for the nestedness of the data (coefficient, standard error (SE), degrees of freedom (df), t-value and $P$-value).

\begin{tabular}{|c|c|c|c|c|c|c|c|c|c|}
\hline \multicolumn{2}{|c|}{ Forest attributes } & \multicolumn{3}{|l|}{ Correlations } & \multicolumn{5}{|c|}{ Mixed linear model $(\mathrm{n}=72)$} \\
\hline & & Celtis $(\mathrm{n}=36)$ & Manilkara $(\mathrm{n}=36)$ & All $(\mathrm{n}=72)$ & Coefficient & SE & df & t-Value & $P$-value \\
\hline \multirow[t]{5}{*}{ Structure } & $S D$ & 0.04 & 0.30 & 0.10 & 0.11 & 0.16 & 63 & 0.66 & 0.508 \\
\hline & $S D_{70}$ & $0.81^{* * * *}$ & $0.63^{k * * *}$ & $0.71^{* * * *}$ & 10.25 & 1.021 & 63 & 10.04 & 0.001 \\
\hline & $B A$ & $0.95^{* k * k}$ & $0.93^{* * * *}$ & $0.94^{* * * *}$ & 17.65 & 0.73 & 63 & 23.91 & 0.001 \\
\hline & $B A_{70}$ & $0.92^{* * * *}$ & $0.86^{* * * *}$ & $0.83^{* * * *}$ & 14.40 & 0.82 & 63 & 17.48 & 0.001 \\
\hline & $D_{\max }$ & $0.72^{* * * *}$ & $0.74^{* * * *}$ & $0.63^{* * *}$ & 4.13 & 0.45 & 63 & 9.01 & 0.001 \\
\hline \multirow[t]{2}{*}{ Composition } & $W D_{\mathrm{m}}$ & $0.67^{* * * *}$ & 0.24 & $0.43^{* * * *}$ & 1775.09 & 285.82 & 63 & 6.21 & 0.001 \\
\hline & $W D_{\mathrm{BA}}$ & $0.62^{* k * k}$ & 0.28 & $0.48^{k * k *}$ & 1068.75 & 219.44 & 63 & 4.87 & 0.001 \\
\hline \multirow[t]{6}{*}{ Architecture } & $H_{\mathrm{m}}$ & 0.20 & 0.32 & 0.21 & 33.09 & 14.49 & 63 & 2.28 & 0.026 \\
\hline & $H_{\mathrm{BA}}$ & $0.84^{* * * *}$ & $0.85^{* \star * *}$ & $0.65^{* * *}$ & 33.41 & 2.76 & 63 & 12.78 & 0.001 \\
\hline & $C d_{\mathrm{m}}$ & $0.34^{*}$ & $0.44^{* * * *}$ & $0.31^{* * * *}$ & 162.05 & 43.81 & 63 & 3.69 & 0.001 \\
\hline & $C d_{\mathrm{BA}}$ & $0.80^{\text {wk*k* }}$ & $0.83^{\text {kik*k}}$ & $0.66^{* * * *}$ & 60.56 & 5.48 & 63 & 11.03 & 0.001 \\
\hline & $\mathrm{Cr}_{\mathrm{m}}$ & $0.46^{* k * *}$ & $0.53^{* * * *}$ & $0.39^{* * * *}$ & 325.01 & 61.97 & 63 & 5.24 & 0.001 \\
\hline & $C r_{\mathrm{BA}}$ & $0.77^{* k * k}$ & $0.81^{* * * *}$ & $0.65^{* * *}$ & 62.79 & 6.20 & 63 & 10.11 & 0.001 \\
\hline
\end{tabular}

\subsection{Crown allometry shapes height-diameter allometry}

In agreement to previous studies in central Africa (Doetterl et al., 2015; Fayolle et al., 2016; Imani et al., 2017), we found that heightdiameter allometry varied between the Celtis and the Manilkara forests, confirming the need of local height-diameter relationships for AGB estimation (Chave et al., 2014; Sullivan et al., 2018). Likewise, the allometric relationship between crown depth and diameter varied between the two forest sites. For a given diameter, trees were taller and had deeper crown in the Celtis forest than in the Manilkara forest. Interestingly, we found that total height-diameter allometry is mostly governed by crown depth rather than height to the first branch between
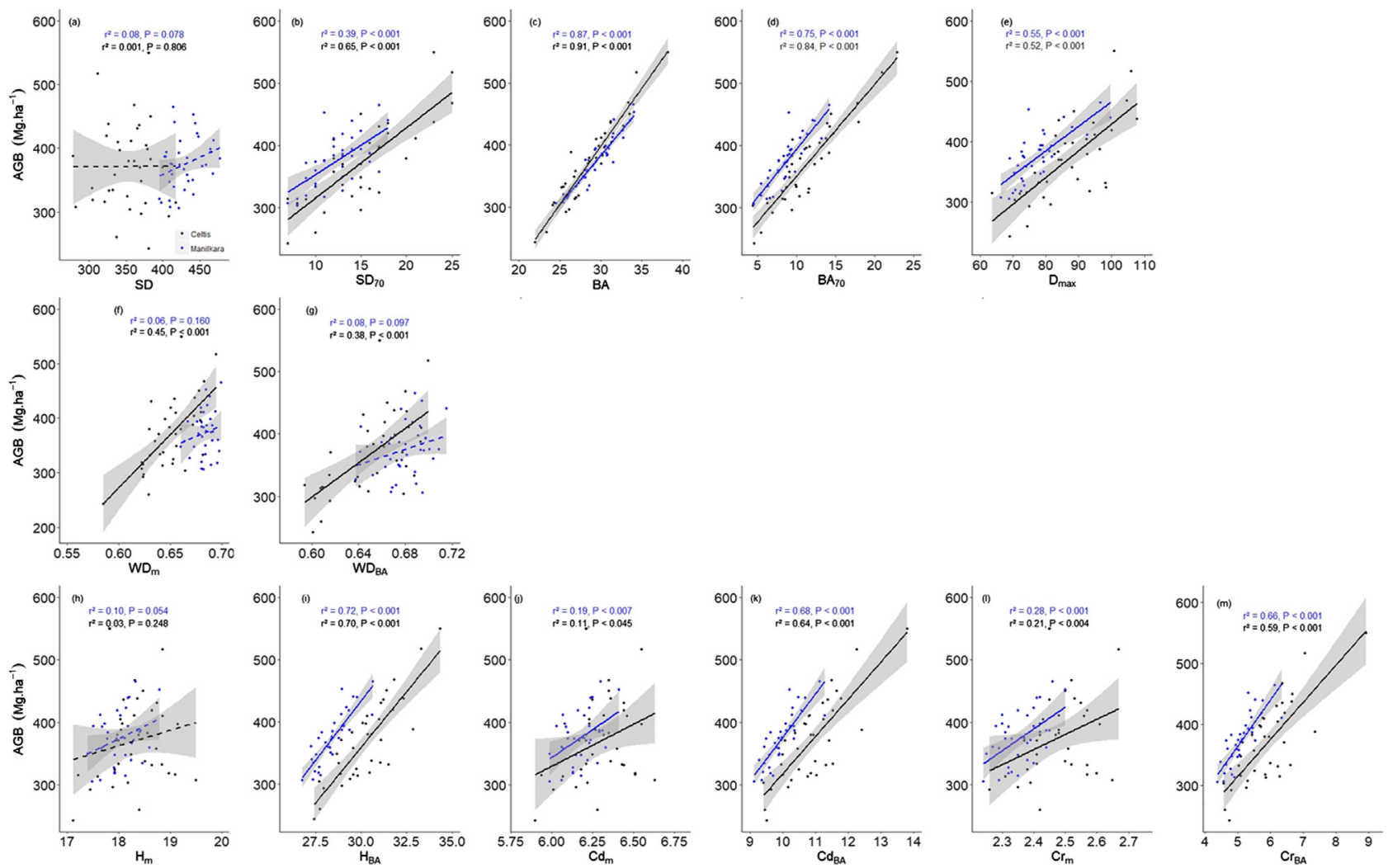

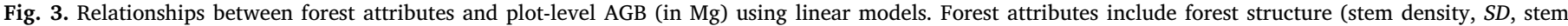

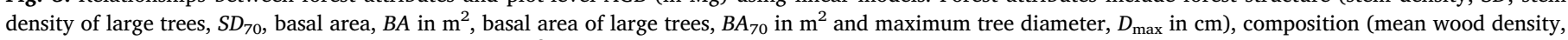

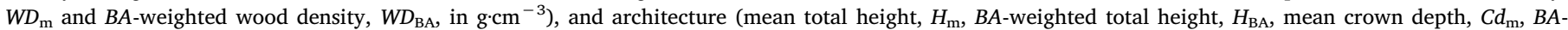

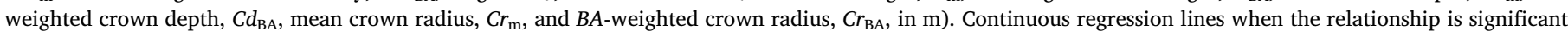

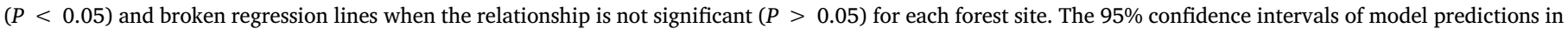
grey and the coefficient of determination $\left(r^{2}\right)$ are given for each regression line. 
the two forest sites for a given diameter. This result implies that volume equations may be applicable in the two types of forest, despite large differences in total tree height.

Contrary to Antin et al. (2013) in the Western Ghats and to Blanchard et al. (2016) in five tropical biogeographic areas that found only little variation in crown allometries, here we showed strong between-site variation in northern Congo, between the Celtis and the Manilkara forest, growing under the same climate but on different geological substrates (Fayolle et al., 2012, 2014). Trees tended to develop large crowns in the Manilkara forest dominated by slow-growing shade tolerant species, that need to develop wide crowns supported by robust branches to minimize self-shading and achieve reproduction at small sizes (King, 1996).

As already underlined above, trees were taller in the Celtis forest, while they tend to develop larger crowns in the Manilkara forest for a given diameter. We found similar trends for the sixteen (16) species shared by both forest sites, suggesting an environmental control of tree allometry. In Borneo, Aiba and Kitayama (1999) already showed that tree allometry is influenced by the geological substrate. In addition, other ecological factors could also be invoked to explain the betweensite variation in tree allometry, such as competition during early succession since stem density and species composition vastly differ between the two forests (Gourlet-Fleury et al., 2011; Réjou-Méchain et al., 2014). The hypothesis of a genetic differentiation can probably be discarded since for shared species, the populations of the Celtis and of the Manilkara forests most likely belong to the same gene pool (Hardy et al., 2013).

\subsection{AGB variation is related to forest structure, composition and architecture}

Among the forest structural attributes, basal area $(B A)$ was found to be the most important determinant of AGB variation, between and within the two forest sites. $B A$ effectively captures the degree to which trees pack and utilize space aboveground (Jucker et al., 2015), which in turn is a key determinant of light interception and growth (Coomes et al., 2014). A strong correlation was found between AGB and BA for the two forest sites, confirming that denser forests have greater AGB, as already shown in central African forest (Lewis et al., 2013; Doetterl et al., 2015; Fayolle et al., 2016). More importantly, we found almost the same relationship between AGB and BA for the two forest sites that, however, vastly differ in forest structure, composition and architecture. This result suggests compensatory effects between forest horizontal and vertical structure, and species composition. Our relationship based on local-scale variation in AGB, is comparable to that of Lewis et al. (2013) obtained with 260 plots across tropical Africa.

High basal area and high AGB were more related to few trees with a large basal area, each containing a disproportionately large AGB, than to many small trees, confirming the importance of large trees for AGB stocks (Bastin et al., 2015; Lutz et al., 2018). Though less important than total $B A$, our results also showed the importance of large trees (tree diameter $\geq 70 \mathrm{~cm}$ ), in basal area $\left(B A_{70}\right)$, and to a lesser extent in density $\left(S D_{70}\right)$, to explain the AGB variation between the two forest sites, in agreement with the results of Lutz et al. (2018) and Slik et al. (2013) across the tropics.

The floristic composition, through mean wood density $\left(W D_{\mathrm{m}}\right)$, was an important explicative variable of AGB variation, specifically for depicting between-site AGB variation, in agreement with the results of Gourlet-Fleury et al. (2011) studying the same forest types but using commercial inventory data. The old-growth Manilkara forest that developed on sandy soils and with a canopy enriched with slow-growing shade tolerant species showed higher wood density on average than the old-secondary Celtis forest that developed on richer soils (Fayolle et al., 2014). Variation in wood density has also been found to determine spatial patterns in forest AGB across Amazonia, with regional scale pattern of species composition linked with a broad gradient of AGB (Baker et al., 2004). Interestingly, we found that wood density was positively correlated with AGB within the Celtis forest, in addition to the between-site variation. The larger species turnover within the Celtis forest, than in the relatively homogenous Manilkara forests (Douh et al., 2018), was indeed associated with a larger range of plot-level wood density.

Ploton et al. (2016) and Jucker et al. (2017) showed that tree AGB was strongly related to tree height and crown size across the tropics. Here for the first time, we demonstrated that architectural attributes (height, crown depth, and crown radius) derived at the plot level from site-specific allometries were good indicators of AGB variation. Plotlevel AGB was correlated to $B A$-weighted total height named Lorey's height, largely used in remote-sensing studies to derive AGB maps (Saatchi et al., 2011) and to $B A$-weighted crown radius, in agreement with the recent results of Meyer et al. (2018) in the Neotropics. The strong relationships found between architectural attributes and AGB offer practical implications to predict plot-level AGB from remotelysensed data (Asner et al., 2012). However, the site-specificity of the relationships is a challenge for the generalization of the approach. In the near future, we believe that these two forest sites established in contrasted ecological conditions will be useful for the calibration of remote-sensing products, since there are a strong local variation in both tree allometry and forest AGB. Linking the ground truth with high-resolution remotely-sensed data, in order to derive architectural attributes seems to be the next step forward for the estimation of AGB at a large scale, without the time-intensive collection of forest inventory data.

\section{Conclusions}

Our study provides important advances for the understanding of local-scale AGB variation in tropical forests. We confirmed that the AGB variation in central African forests depends on forest structure (basal area) and architecture (height and crown dimensions), and to a lesser extent composition (wood density). These results offer the opportunity for practical implications for AGB and carbon stocks monitoring in central Africa, and specifically for the calibration of remote-sensing products.

\section{Acknowledgements}

This work was supported by the DynAfFor project supported by a French Fund for the Global Environment (grant numbers Nos. CZZ1636.01D and CZZ1636.02D); International Foundation for Science (grant number D/5822-1); F.R.S-FNRS (grant number 2017/v3/5/332 IB/JN - 9500), Nature + (asbl, Belgium) and the Republic of Congo (OGES-Congo). The fieldwork of this study was conducted in the permanent design of DynAfFor and P3FAC projects, supported by the French Fund for the Global Environment, implemented by ATIBT/ COMIFAC/Nature + /CIRAD/Gembloux Agro-Bio Tech/CIB-Olam and Mokabi SA logging companies. We thank the team members of CIBOlam and MOKABI SA logging companies. The authors are specifically thankful to Mercier Mayinga (CIB-Olam) and Arnaud N'Gokaka (Mokabi SA) for facilitating field measurements. We are grateful to Dr. Jean-François Gillet for help with plant identification. We are deeply grateful to Ecology group of the School of Geography during our research visit at the University of Exeter (UK).

\section{Appendix A}

Characteristics of the 16 species shared by the two forest sites (Celtis and Manilkara). Family name, the number of trees and the range of diameter 
(in $\mathrm{cm}$ ) are indicated for each species.

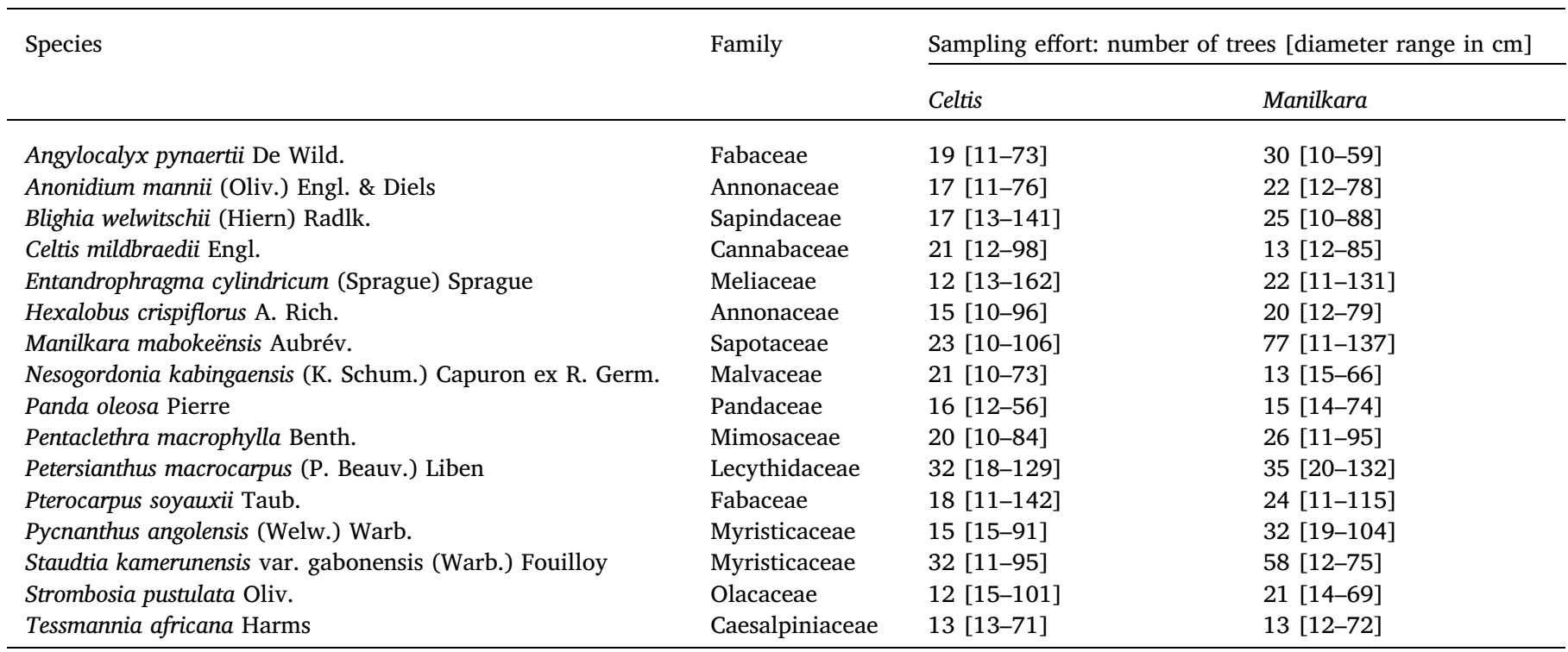

\section{Appendix B. Supplementary material}

Supplementary data associated with this article can be found, in the online version, at https://doi.org/10.1016/j.foreco.2018.07.056.

\section{References}

Aiba, S.I., Kitayama, K., 1999. Structure, composition and species diversity in an altitudesubstrate matrix of rain forest tree communities on Mount Kinabalu. Borneo. Plant Ecol. 140, 139-157.

Akaike, H., 1974. A new look at the statistical model identification. IEEE Trans. Automat. Control 19 (6), 716-723.

Antin, C., Pélissier, R., Vincent, G., Couteron, P., 2013. Crown allometries are less responsive than stem allometry to tree size and habitat variations in an Indian monsoon forest. Trees - Struct. Funct. 27, 1485-1495. https://doi.org/10.1007/s00468-0130896-7.

Asner, G.P., Mascaro, J., Muller-Landau, H.C., Vieilledent, G., Vaudry, R., Rasamoelina, M., Hall, J.S., van Breugel, M., 2012. A universal airborne LiDAR approach for tropical forest carbon mapping. Oecologia 168, 1147-1160. https://doi.org/10.1007/ s00442-011-2165-z.

Avitabile, V., Herold, M., Heuvelink, G.B.M., Lewis, S.L., Phillips, O.L., et al., 2016. An integrated pan-tropical biomass map using multiple reference datasets. Glob. Chang. Biol. 22, 1406-1420. https://doi.org/10.1111/gcb.13139.

Baker, T.R., Phillips, O.L., Malhi, Y., Almeida, S., Arroyo, L., Di Fiore, A., et al., 2004. Variation in wood density determines spatial patterns in Amazonian forest biomass. Glob. Chang. Biol. 10 (5), 545-562. https://doi.org/10.1111/j.1365-2486.2004. 00751.x.

Bastin, J.-F., Barbier, N., Réjou-Méchain, M., Fayolle, A., Gourlet-Fleury, S., Maniatis, D., et al., 2015. Seeing Central African forests through their largest trees. Sci. Rep. 5, 13156. https://doi.org/10.1038/srep13156.

Blanchard, E., Birnbaum, P., Ibanez, T., Boutreux, T., Antin, C., Ploton, P., Vincent, G., et al., 2016. Contrasted allometries between stem diameter, crown area, and tree height in five tropical biogeographic areas. Trees - Struct. Funct. 30, 1953-1968. https://doi.org/10.1007/s00468-016-1424-3.

Chave, J., Coomes, D., Jansen, S., Lewis, S.L., Swenson, N.G., Zanne, A.E., 2009. Towards a worldwide wood economics spectrum. Ecol. Lett. 12, 351-366. https://doi.org/10. 1111/j.1461-0248.2009.01285.x.

Chave, J., Réjou-Méchain, M., Búrquez, A., Chidumayo, E., Colgan, M.S., et al., 2014. Improved allometric models to estimate the aboveground biomass of tropical trees. Glob. Change Biol. 20, 3177-3190. https://doi.org/10.1111/gcb.12629.

Coomes, D.A., Flores, O., Holdaway, R., Jucker, T., Lines, E.R., Vanderwel, M.C., 2014 Wood production response to climate change will depend critically on forest composition and structure. Glob. Change Biol. 20, 3632-3645. https://doi.org/10.1111/ gcb.12622.

Doetterl, S., Kearsley, E., Bauters, M., Hufkens, K., Lisingo, J., Baert, G., Verbeeck, H., Boeckx, P., 2015. Aboveground vs. belowground carbon stocks in African tropical lowland rainforest: Drivers and implications. PLoS One 10, 1-14. https://doi.org/10. 1371/journal.pone.0143209.

Douh, C., Daïnou, K., Loumeto, J.J., Moutsambote, J.M., Fayolle, A., Tosso, F., Doucet, J.L., 2018. Soil seed bank characteristics in two central African forest types and implications for forest restoration. For. Ecol. Manage. 409, 766-776. https://doi.org/ 10.1016/j.foreco.2017.12.012
Eggleston, H.S., Buendia, L., Miwa, K., Ngara, T., Tanabe, K., 2006. Guidelines for national greenhouse gas inventories Technical Report 4 Intergovernmental Panel on Climate Change (IPCC) IGES, Japan Prepared by the National Greenhouse Gas Inventories Programme.

Fayolle, A., Engelbrecht, B., Freycon, V., Mortier, F., Swaine, M., et al., 2012. Geological substrates shape tree species and trait distributions in African moist forests. PLoS One 7, 12-14. https://doi.org/10.1371/journal.pone.0042381.

Fayolle, A., Picard, N., Doucet, J.L., Swaine, M., Bayol, N., Bénédet, F., Gourlet-Fleury, S., 2014. A new insight in the structure, composition and functioning of central African moist forests. For. Ecol. Manage. 329, 195-205. https://doi.org/10.1016/j.foreco. 2014.06.014.

Fayolle, A., Loubota Panzou, G.J., Drouet, T., Swaine, M.D., Bauwens, S., et al., 2016. Taller trees, denser stands and greater biomass in semi-deciduous than in evergreen lowland central African forests. For. Ecol. Manage. 374, 42-50. https://doi.org/10. 1016/j.foreco.2016.04.033.

Feldpausch, T.R., Lloyd, J., Lewis, S.L., Brienen, R.J.W., Gloor, M., et al., 2012. Tree height integrated into pantropical forest biomass estimates. Biogeosciences 9, 3381-3403. https://doi.org/10.5194/bg-9-3381-2012.

Goodman, R.C., Phillips, O.L., Baker, T.R., 2014. The importance of crown dimensions to improve tropical tree biomass estimates. Ecol. Appl. 24, 680-698. https://doi.org/10. 1890/13-0070.1.

Gourlet-Fleury, S., Rossi, V., Rejou-Mechain, M., Freycon, V., Fayolle, A., et al., 2011. Environmental filtering of dense-wooded species controls above-ground biomass stored in African moist forests. J. Ecol. 99, 981-990. https://doi.org/10.1111/j.13652745.2011.01829.x.

Hardy, O.J., Born, C., Budde, K., Daïnou, K., Dauby, G., et al., 2013. Comparative phylogeography of African rain forest trees: a review of genetic signatures of vegetation history in the Guineo-Congolian region. Comptes Rendus - Geosci. 345, 284-296. https://doi.org/10.1016/j.crte.2013.05.001.

Imani, G., Boyemba, F., Lewis, S., Nabahungu, N.L., Calders, K., et al., 2017. Heightdiameter allometry and above ground biomass in tropical montane forests: Insights from the Albertine Rift in Africa. PLoS One 12, 1-20. https://doi.org/10.1371/ journal.pone.0179653.

Jucker, T., Bouriaud, O., Coomes, D.A., 2015. Crown plasticity enables trees to optimize canopy packing in mixed-species forests. Funct. Ecol. 29, 1078-1086. https://doi org/10.1111/1365-2435.12428.

Jucker, T., Caspersen, J., Chave, J., Antin, C., Barbier, N., et al., 2017. Allometric equations for integrating remote sensing imagery into forest monitoring programmes. Glob. Chang. Biol. 23, 177-190. https://doi.org/10.1111/gcb.13388.

Kearsley, E., de Haulleville, T., Hufkens, K., Kidimbu, A., Toirambe, B., et al., 2013. Conventional tree height-diameter relationships significantly overestimate aboveground carbon stocks in the Central Congo Basin. Nat. Commun. 4, 2269. https://doi. org/10.1038/ncomms3269.

King, D.A., 1996. Allometry and life history of tropical trees. J. Trop. Ecol. 12, 25-44 https://doi.org/10.1017/S0266467400009299.

Lewis, S.L., Lopez-Gonzalez, G., Sonké, B., Affum-Baffoe, K., Baker, T.R., et al., 2009. Increasing carbon storage in intact African tropical forests. Nature 457, 1003-1006. https://doi.org/10.1038/nature07771. 
Lewis, S., Sonké, B., Sunderland, T., Begne, S.K., Lopez-Gonzalez, G., et al., 2013. Aboveground biomass and structure of 260 African tropical forests. Philos. Trans. R. Soc. Lond. B. Biol. Sci. 368, 20120295.

Loubota Panzou, G.J., Doucet, J.L., Loumeto, J.J., Biwole, A., Bauwens, S., Fayolle, A., 2016. Biomasse et stocks de carbone des forêts tropicales africaines (synthèse bibliographique). Biotechnol. Agron. Soc. Environ. 20, 508-522.

Lutz, J.A., Furniss, T.J., Johnson, D.J., Davies, S.J., Allen, D., Alonso, A., et al., 2018. Global importance of large-diameter trees. Glob. Ecol. Biogeogr. https://doi.org/10. 1111/geb.12747. (in press).

Meyer, V., Saatchi, S., Clark, D.B., Keller, M., Vincent, G., et al., 2018. Canopy area of large trees explains aboveground biomass variations across neotropical forest landscapes. Biogeosciences 15, 3377-3390. https://doi.org/10.5194/bg-15-3377-2018.

Mitchard, E.T.A., Feldpausch, T.R., Brienen, R.J.W., Lopez-Gonzalez, G., Monteagudo, A. et al., 2014. Markedly divergent estimates of Amazon forest carbon density from ground plots and satellites. Glob. Ecol. Biogeogr. 23, 935-946. https://doi.org/10. 1111/geb.12168.

Pan, Y., Birdsey, R., Fang, J., Houghton, R.A., Kauppi, P., et al., 2011. A Large and Persistent Carbon Sink in the World's Forests. Science 333, 988-994.

Pinheiro, J., Bates, D., DebRoy, S., Sarkar, D., R Core Team, 2017. nlme: Linear and Nonlinear Mixed Effects Models. R package version 3.1-131, < https://CRAN.Rproject.org $/$ package $=$ nlme $>$.

Ploton, P., Barbier, N., Momo, S.T., Rejou-Mechain, M., Boyemba Bosela, F., et al., 2016. Closing a gap in tropical forest biomass estimation: taking crown mass variation into account in pantropical allometries. Biogeosciences 13, 1571-1585. https://doi.org/ 10.5194/bg-13-1571-2016.

R Core Team, 2017. version 3.4.1. R: A Language and Environment for Statistical Computing. R Foundation for Statistical Computing, Vienna, Austria.

Réjou-Méchain, M., Flores, O., Pélissier, R., Fayolle, A., Fauvet, N., Gourlet-Fleury, S., 2014. Tropical tree assembly depends on the interactions between successional and soil filtering processes. Glob. Ecol. Biogeogr. 23, 1440-1449. https://doi.org/10. 1111/geb.12222.

Réjou-Méchain, M., Tanguy, A., Piponiot, C., Chave, J., Hérault, B., 2017. Biomass: an R package for estimating above-ground biomass and its uncertainty in tropical forests. Methods Ecol. Evol. 8, 1163-1167. https://doi.org/10.1111/2041-210X.12753.

Saatchi, S.S., Harris, N.L., Brown, S., Lefsky, M., Mitchard, E.T., Salas, W., et al., 2011. Benchmark map of forest carbon stocks in tropical regions across three continents. PNAS 108 (24), 9899-9904. https://doi.org/10.1073/pnas.1019576108.

Slik, J.W.F., Paoli, G., McGuire, K., Amaral, I., Barroso, J., et al., 2013. Large trees drive forest aboveground biomass variation in moist lowland forests across the tropics. Glob. Ecol. Biogeogr. 22, 1261-1271. https://doi.org/10.1111/geb.12092.

Sullivan, M.J.P., Lewis, S.L., Hubau, W., Qie, L., Baker, T.R., et al., 2018. Field methods for sampling tree height for tropical forest biomass estimation. Methods Ecol. Evol. 9, 1179-1189. https://doi.org/10.1111/2041-210X.12962.

Verbeeck, H., Boeckx, P., Steppe, K., 2011. Tropical forests: include Congo basin. Nature 479 (7372), 179. https://doi.org/10.1038/479179b.

Zanne, A., Lopez-Gonzalez, G., Coomes, D.A., Ilic, J., Jansen, S., et al., 2009. Towards a worldwide wood economics. Spectrum. https://doi.org/10.5061/dryad.234. 